\title{
The Lebanese in Sydney
}

\section{Anne Monsour and Paul Convy}

Since their arrival in the second half of the nineteenth century, the Lebanese in Sydney have made the city their home and have endeavoured to contribute positively to their new society as full and active citizens, despite their status as 'undesirable immigrants' and the extensive legislative discrimination they faced as non-Europeans. Through enterprise and hard work, they have sought to achieve economic well-being for their families and better prospects for their children. The Lebanese community in Sydney is heterogeneous, although Arabic-speaking, and for over 100 years has contributed to the city's cultural and religious diversity.

\section{A long history}

Noticeable numbers of Lebanese arrived in Australia during the 1880s and the port of Sydney was their most important point of entry. ${ }^{1}$ By 1892, Lebanese in Sydney were identified as living in 'a rather large colony' in Redfern. Throughout the 1890s, the number of Lebanese entering Australia increased dramatically but this increase was effectively slowed by the implementation of the Immigration Restriction Act of $1901 .^{2}$ After this year, the decision to come to Australia was no longer as simple as being able to afford the fare; for Lebanese, classified as Asians by the Act, entry was now dependent on passing the dictation test, having an exemption permit approved by the Minister, or being considered eligible for an exemption permit by being a former resident, or the wife or child of a man not deemed a 'prohibited immigrant'. ${ }^{3}$ However, in contrast with other Asians, Lebanese were not totally excluded although their entry was restricted and closely monitored. The success of immigration restriction meant that until the 1960s, the number of Lebanese immigrants in Australia was always small and only people with established family or friends were admitted. ${ }^{4}$ This changed after World War II when due to gradual changes in immigration policies and priorities, increasing numbers of Lebanese were granted entry. ${ }^{5}$ Another significant intake occurred after 1976 in response to people fleeing the Lebanese civil war (19761990). ${ }^{6}$ While Lebanese settled all over Australia, the majority have consistently settled in NSW and particularly in Sydney. According to Burnley, in 1996, 72 per cent of Lebanese in Australia lived in Sydney. The largest proportion of the Lebanese community in Australia, whether it includes those who were born overseas or also those who claim Lebanese ancestry, now lives in the Sydney metropolitan area. $^{7}$

\section{Syrians and Lebanese}

When the first immigrants arrived in Australia they were called Syrians. The focus of an Illustrated Sydney News article in 1892 was, for example, 'the Syrian colony in Redfern'. ${ }^{8}$ Under Ottoman rule, modern Lebanon was part of the province of Syria so the term Syrian was 
technically correct, as was the classification of these immigrants as Turkish subjects, but neither classification was based on how these people identified or thought about themselves. Unfamiliar with the modern concept of national identity, they were loyal instead to their family, religious sect and village. ${ }^{9}$ In the absence of a national identity, the term Syrian was accepted as a political expedient when, as immigrants, a collective identity became necessary but it did not signify the existence of a cohesive group. ${ }^{10}$ While the use of the term Lebanese slowly increased after Lebanon was created as a French Mandate in $1920,{ }^{11}$ in Australia, Syrian and Lebanese did not officially become separate categories until the 1940s. ${ }^{12}$ The immigrants themselves did not use the term Lebanese widely until the same time. ${ }^{13}$ This helps explain why it is mistakenly thought that Lebanese did not come to Australia until the second part of the twentieth century. Despite the creation of a Lebanese national identity, Lebanese in Sydney still tend to congregate and to develop organisations based on their village and religious affiliations.

\section{Lebanese Sydney}

Sydney has always been the most important centre of Lebanese settlement in Australia. ${ }^{14}$ By the 1880s, Lebanese had settled in and around the inner Sydney suburbs of Redfern, Surry Hills and Waterloo. The Syrian quarter ran along a north/south axis of Elizabeth Street and was centred opposite Redfern Park. ${ }^{15}$ In 1892, the 'Syrian colony' in Redfern included 23 shops and by the end of the decade several Syrian men had established warehouses and factories. ${ }^{16}$ In 1909, six of these Lebanese businessmen, JG Malouf, George Dan, Stanton Melick, Anthony and Simon Coorey and Naser Abdullah, were recognised for their business acumen, good citizenship and support of charitable works in a Jubilee booklet published by Redfern Municipal Council.

The central location of Lebanese-owned wholesaling and warehousing businesses and factories in Redfern attracted other Lebanese seeking work and was a convenient place from which to supply hawkers and small rural and suburban businesses. Redfern was the economic hub for the community and only declined in importance in the last decades of the twentieth century. Indeed in 1982, Ian Burnley described the continuous, century-long Lebanese 'presence' in Redfern as 'the longest continuously occupied ethnic residential settlement in any Australian city’. ${ }^{17}$

Although new immigrants continued to begin their life in Australia in Redfern, by the 1920s, established Lebanese were moving and settling in other suburbs of Sydney. Initially, they relocated to suburbs such as Coogee, Kingsford and Kensington which were just a tram ride away from Redfern. Later, wealthier Lebanese moved to more affluent areas like Bellevue Hill and Vaucluse in the east and Strathfield, in the west. A substantial increase in the number of Lebanese immigrants in the 1960s added to the Redfern community and led to a further dispersal of Lebanese, particularly to inner western suburbs such as Campsie, Marrickville, Hurlstone Park and Croydon. Due to government immigration policies whereby only people with family or friends already established in Australia and able to provide initial support were granted entry and 
to strong family and village ties, Lebanese immigration has been characterised by chain migration which has in turn determined settlement patterns. A sizable settlement in Thornleigh of Lebanese from the village of Bann, for example, is the result of one family settling there in 1925 and subsequently encouraging people from their home village to join them. ${ }^{18}$ The major focus of settlement for people from the village of Kfarsghab, who were part of the early Lebanese migration to Australia, has been Parramatta, especially the suburb of Harris Park. Parramatta is so important as a centre of Kfarsghabi settlement that the two-kilometre main street of the village in Lebanon has been renamed Parramatta Road. ${ }^{19}$ Since the 1960s, people from the village of Hadchit have also settled in Parramatta and there are now about 500 Hadchiti households in Westmead and Harris Park. ${ }^{20}$ Currently, both the Canterbury local government area (LGA) and the Parramatta LGA have significant concentrations of Lebanese.

\section{Work and business}

Lebanese in Sydney have followed a distinctive occupational pattern characterised by high levels of self-employment, particularly in petty commercial activities such as hawking and shopkeeping. According to Collins et al, in 1901, '80 per cent of Lebanese in NSW were concentrated in commercial occupations' - in 1947, little had changed, as 60 per cent of Lebanese were 'either employers or self-employed'. Even in the 1991 census, Lebanese men and women were 'noticeably over-represented as self-employed'. ${ }^{21}$

By the early 1890s, several Lebanese had established warehouses and factories in Redfern. ${ }^{22}$ As Jim McKay observed, this group developed a 'near monopoly on incoming Syrian [Lebanese] labour', and it was because of these 'economic gatekeepers' in Redfern that almost all Lebanese immigrants took up hawking as their first occupation. An enduring pattern developed where new arrivals worked as hawkers until they had enough capital to set up their own small businesses. As well as providing employment in their Redfern factories, the Lebanese warehousemen supplied goods and credit to Lebanese hawkers and were major suppliers to the rural network of Lebanese small businesses. ${ }^{23}$ The significant economic role of Lebanese women is a distinguishing and perhaps unexpected characteristic of early Lebanese settlement in Australia. In 1892, the Illustrated Sydney News portrayed the 'typical Syrian hawker' as a woman with a child on her hip and a basket of goods on her arm, and claimed these women were a familiar sight in most Australian cities. This representation was accurate. Many Lebanese women worked as hawkers and also played a vital role in the running of both family and independent businesses. ${ }^{24}$ Successful entrepreneurship, big and small, is a persistent characteristic of Sydney's Lebanese community. ${ }^{25}$.

However, since the 1950s, economic changes and increased numbers of Lebanese have meant occupational pathways have been more diverse. While 'the small business tradition continued', many Lebanese men and women found paid employment in factories. ${ }^{26}$ Some of these factories, 
such as the Sunbeam plant, were located near Redfern. When the Redfern Mail Exchange was built in the early 1960s, Lebanese found employment as postal sorters. Lebanese also worked in the ACI Glassworks, the Tooths Brewery, and the British Motor Works plants at Waterloo and Zetland. From the 1960s to the 1980s Lebanese-born men and women in Sydney were concentrated as manual labourers, production process workers and in trade activities. Due to structural changes in the Australian economy which resulted in the loss of semiskilled and unskilled jobs, the influx of Lebanese to Sydney after 1976 because of the Lebanese civil war and prejudice against the employment of 'Arabs', since the 1980s, Lebanese have experienced persistently high levels of unemployment. Although some Lebanese families have become very wealthy, Lebanese in Sydney are disproportionately concentrated among the unemployed and the low-income families. ${ }^{27}$

\section{Religion, family and village}

The Lebanese in Sydney are religiously diverse and generally associate according to religious sect and family and village ties. Prior to 1947, Lebanese immigrants were overwhelmingly Christian (mainly Maronite, Melkite and Orthodox) with a small number of Druze who settled mainly in South Australia. With the exception of the Druze in Adelaide (1891), the Muslim Lebanese came later. Lebanese Muslim families (mainly Sunnis and Shi'ites) began arriving in the 1950s, and by 199638.6 per cent of Lebanese-born migrants were Muslim. About 74 per cent of these live in NSW, with the majority in Sydney. ${ }^{28}$

The rapid establishment of their own churches and mosques demonstrates the importance of religious sect for the Lebanese immigrants. The Melkites had established a church in Waterloo by 1895, and the Maronites had their own church in Redfern by $1897 .{ }^{29}$ From 1898, the Lebanese Orthodox community attended the Holy Trinity Orthodox Church in Surry Hills until they built the St George Antiochian Orthodox Church in Redfern in $1920 .^{30}$ Since the 1960s, suburbanisation and increased numbers have resulted in the building of new Maronite, Melkite and Orthodox churches.

Initially, Lebanese Muslims settled in Canterbury. In the early 1960s, a house in Lakemba was used as a mosque and this later became the site for the Imam Ali Mosque which is predominantly Lebanese Sunni Muslim. To meet the needs of a growing number of Lebanese Shi'ah Muslims, the al-Zahra mosque was built in Arncliffe in $1983 .{ }^{31}$ Each of the religious communities has developed a range of religious and community organisations.

Over forty village societies, which provide welfare and cultural services, are also located in the Sydney metropolitan area. The Australian Kfarsghab Lebanese Association, formed in 1952, is the oldest village society. ${ }^{32}$ The second oldest, the Becharrie Charitable Association, was formed 
in $1961 .^{33}$ The Lebanese Community Council is an umbrella group of over 40 Lebanese organisations with representatives of all religions and political persuasions.

\section{Organisations and citizenship}

The Lebanese who settled in Sydney have participated enthusiastically in social institutions, cultural and sporting events and civic affairs. The Lebanese-born population is characterised by very high levels of Australian citizenship. In 2000, Australian citizenship was almost universal among those who had arrived more than 15 years previously (98.3 per cent) and also very high among those who arrived later (85.4 per cent). ${ }^{34}$

Lebanese civic organisations have a long history in Sydney. The Australian Syrian/Lebanese Association operated in Sydney from the 1920s to 1940s. The Australian Lebanese Association (NSW Branch) was formed in 1949 as a non-sectarian peak organisation to consider the interests of the Lebanese community as a whole. ${ }^{35}$ Still in existence with premises and staff in Dulwich Hill, it provides services to all members of the Lebanese community.

A significant number of Lebanese Sydneysiders have served and continue to serve on municipal councils in the Sydney area. George Dan was first elected to Randwick Council in 1944 and served terms as deputy Mayor and Mayor over the next two decades. Sir Nicholas 'Nick' Shehadie became Lord Mayor of Sydney in 1973-75. Shaoquett Moselmane has been Mayor of the City of Rockdale. ${ }^{36}$ Lebanese Australians have also been prominent in State politics. Alexander Alam was one of the longest serving members of the New South Wales Legislative Council. Barbara Perry, the Labor Member for Auburn, the first woman of Lebanese ancestry to hold a parliamentary seat, was Minister for Juvenile Justice, Western Sydney and assisting the Premier on Citizenship in 2008. First elected in 1990, Daryl Melham, the son of Lebanese immigrants, is the Federal Member for the Sydney seat of Banks. The Governor of NSW from 2001 until 2011, Professor Marie Bashir, is the granddaughter of pioneer Lebanese wholesalers in Redfern.

\section{Discrimination and hostility}

The early Lebanese settlers were identified as non-white, non-European and undesirable. Officially classified as Asian, they were subject to a wide range of institutionalised discrimination imposed by State and Commonwealth legislation. ${ }^{37}$ As 'aboriginal natives of Asia', for example, they were excluded from citizenship by the Naturalisation Act of 1903 until the racial disqualification was removed by the Nationality Act of $1920 .{ }^{38}$ Lebanese adamantly rejected their classification as Asian, insisting they were white and European. Indeed, due to an obvious confusion about their actual identity, they were granted special exemptions from some of the restrictions imposed by anti-Asian legislation and gained qualified acceptance at an official level. ${ }^{39}$ Their acceptance as honorary southern Europeans was based on their physical 
appearance, religion and the presence of a significant proportion of women. ${ }^{40}$ For most of the twentieth century, Lebanese recognised that to be accepted as good citizens rather than as undesirable aliens, it was necessary to disguise their differences and to conceal their Arabic background. ${ }^{41}$ Since the 1970 s, changes in government policies such as the move from assimilation to multiculturalism have encouraged Australians to be more open about their cultural and religious backgrounds; yet despite this apparent move towards cultural diversity, in early twenty-first century Australia the acceptance of Lebanese is under public scrutiny. This is particularly true in Sydney where racial profiling by police, politicians and the media has focused negative attention on the 'Lebanese'. ${ }^{42}$ Additionally, events such as the Gulf War and September 11, 2001 generated worldwide hostility towards Arabs and Muslims. The degree of hostility directed towards Lebanese in Sydney was demonstrated by the racial violence at Cronulla beach in December 2005. At the beginning of the twentieth century, there were doubts about the desirability of Lebanese as immigrants; in the first decade of the twenty-first century, the acceptability of Lebanese in Australia is yet again being appraised.

As non-Europeans, Eastern Christians, and Muslims, Lebanese have confronted two significant divides in Australian society, race and religion; yet, they have also contributed to the multicultural and religiously diverse character of Sydney. Welcome or not, Lebanese have certainly embraced Sydney as their home and the personal and collective stories of the immigrants and their descendants are inexorably part of the city's heritage.

Anne Monsour teaches at Central Queensland University and is convenor of the Queensland branch of the Australian Lebanese Historical Society

Paul Convy is Secretary of the Australian Lebanese Historical Society, Sydney

\section{Endnotes}

1 Jim McKay, Phoenician Farewell: Three Generations of Lebanese Christians in Australia, Ashwood House Academic, Melbourne, 1989, p 34

2 Anne Monsour, 'Negotiating a Place in a White Australia: Syrian/Lebanese in Australia, 1880 to 1947, a Queensland Case Study', PhD thesis, University of Queensland, 2004, pp 51-52

3 Barry York, Immigration Restriction, 1901-1957, Studies in Australian Ethnic History, Number 1, Centre for Immigration and Multicultural Studies, Canberra, 1992, p 2

4 Anne Monsour, 'Negotiating a Place in a White Australia: Syrian/Lebanese in Australia, 1880 to 1947, a Queensland Case Study', PhD thesis, University of Queensland, 2004, pp 112, 371; Michael Humphrey, 'Lebanese since 1970', in James Jupp (ed), The Australian People, 2nd ed, Cambridge University Press, Cambridge, 2001, p 561

5 Jim McKay \& Trevor Batrouney, 'Lebanese immigration until the 1970s', in James Jupp (ed), The Australian People, 2nd ed, Cambridge University Press, Cambridge, 2001, p 558

6 Michael Humphrey, 'Lebanese since 1970', in James Jupp (ed), The Australian People, 2nd ed, Cambridge University Press, Cambridge, 2001, p 561 


\section{Endnotes}

7 Australian Bureau of Statistics; Ian H Burnley, The Impact of Immigration on Australia: A demographic Approach, Oxford University Press, Melbourne, 2001, p 196

8 Illustrated Sydney News, 19 November 1892, p 4

9 Almost every discussion of Syrian/Lebanese immigrants makes this point. See the following as examples: Philip K Hitti, The Syrians in America, George H Doran, New York, 1924, p 25; Michael W Suleiman, 'Early Arab-Americans: The Search for Identity', in Eric J Hooglund (ed), Crossing the Waters: Arabicspeaking immigrants to the United States before 1940, Smithsonian Institution Press, Washington DC, 1987, pp 41, 47; Kemal H Karpat, 'The Ottoman Emigration to America 1860-1914', International Journal of Middle East Studies, 17, 1985, pp 175-209; Marlene Khoury Smith, 'The Arabic-Speaking Community in Rhode Island: A Survey of the Syrian and Lebanese Communities in Rhode Island', in Joan H Rollins (ed), Hidden Minorities: The Persistence of Ethnicity in American Life, University Press of America, Washington , 1981, p 141

10 Anne Monsour, 'Negotiating a Place in a White Australia: Syrian/Lebanese in Australia, 1880 to 1947, a Queensland Case Study', PhD thesis, University of Queensland, 2004, p 47

11 Nicola A Ziadeh, Syria and Lebanon, Librairie Du Liban, and Longmans, Beirut, 1968, p 50

12 This change appears to have occurred after the French Consul General in Australia wrote to William Hughes, the Minister for External Affairs, pointing out that 'politically and administratively, Syria and Lebanon are separate'. Commonwealth Statistician to Secretary, Department of the Interior, 38/32817, 30 December 1938, A1/1, 38/32817, National Archives of Australia (NAA) (ACT); J Tremoulet, Consul General of France to William M Hughes, Minister for External Affairs, No 202, 18 November 1938, A1/1, 38/32817, NAA (ACT)

13 Jim McKay \& Trevor Batrouney, 'Lebanese immigration until the 1970s', in James Jupp (ed), The Australian People, 2nd ed, Cambridge University Press, Cambridge, 2001, p 555

14 Ian H Burnley, 'Lebanese Migration and Settlement in Sydney, Australia', International Migration Review, vol 16, no 1, Spring, 1982, pp 102-32

15 Paul Convy, The Lebanese Quarter: Mapping the Syrian/Lebanese Quarter at Redfern -Time, Place and Extent, Australian Lebanese Historical Society Inc, Coogee, 2006

16 Illustrated Sydney News, 19 November 1892, p 4; Souvenir to Commemorate the 50th Anniversary of the Incorporation of the Municipality of Redfern, 1859-1909 McBarron, Stewart \& Co, Sydney, 1909

17 Ian H Burnley, 'Lebanese Migration and Settlement in Sydney, Australia', International Migration Review, vol 16, no 1, Spring, 1982, p 106

18 'Pioneer Lebanese Catholic Family: Anthony Peter Baynie, 1892-1991', Annals Australia, October/November 1991, p 25; Ian H Burnley, The Impact of Immigration on Australia: A demographic Approach, Oxford University Press, Melbourne, 2001, p 196

19 Rachel Morris, 'Now Sydney’s most famous road stretches to Lebanon', Daily Telegraph, 8 May 2002, p 23

20 Nelia Hyndman-Rizik, 'The Hadchiti Disapora: A Re-territorialized Lebanese Village in Western Sydney', Newsletter of the Australian Lebanese Historical Society, no 20, Summer, 2005, pp 5-7

21 Jock Collins et al, A Shop Full of Dreams: Ethnic Small Business in Australia, Pluto Press, Leichhardt NSW, 1995, pp 40, 74

22 Souvenir to Commemorate the 50th Anniversary of the Incorporation of the Municipality of Redfern, 1859-1909 McBarron, Stewart \& Co, Sydney, 1909 


\section{Endnotes}

23 Jim McKay, Phoenician Farewell: Three Generations of Lebanese Christians in Australia, Ashwood House Academic, Melbourne, 1989, pp 40-42

24 Anne Monsour, 'Sitti was a Hawker! Writing Syrian/Lebanese Women into Queensland History', in Wendy Madsen and Angelika Schlotzer (eds), Smashing the Glass Ceiling: Women Researchers in a Regional Community, Centre for Social Science Research, CQU, Rockhampton, 2002, pp 1-11; Anne Monsour, 'Not Two Steps Behind But Side By Side-the Economic Role of Syrian/Lebanese Women in Queensland From the 1880s to 1947', in Australian Lebanese Historical Society, Records Made Real: Lebanese Settlement 1865 to 1945 - a Seminar on Historical Sources, the author, Sydney, 2002, pp 4958

25 Jock Collins, 'From Beirut to Bankstown: The Lebanese Diaspora in Multicultural Australia', in Paul Tabar (ed), Lebanese Diaspora: History, Racism and Belonging, Lebanese American University, Beirut, 2005, pp 187-211

26 Jock Collins et al, A Shop Full of Dreams: Ethnic Small Business in Australia, Pluto Press, Leichhardt NSW, 1995, p 73

27 Jock Collins, 'From Beirut to Bankstown: The Lebanese Diaspora in Multicultural Australia', in Paul Tabar (ed), Lebanese Diaspora: History, Racism and Belonging, Lebanese American University, Beirut, 2005, pp 194, 205, 203

28 Michael Humphrey, 'Lebanese since 1970', in James Jupp (ed), The Australian People, 2nd ed, Cambridge University Press, Cambridge, 2001, p 564

29 Jim McKay, Phoenician Farewell: Three Generations of Lebanese Christians in Australia, Ashwood House Academic, Melbourne, 1989, pp 49-50

30 ‘Greek Orthodox Church: Foundation-stones Laid’, Sydney Morning Herald, 30 May 1898; Emil N Dan, 'A History of St George Cathedral', in St George Cathedral and Its People: Past, Present and Future, Longueville Media, Sydney, 2004, p 26

31 Michael Humphrey, 'Lebanese since 1970', in James Jupp (ed), The Australian People, 2nd ed, Cambridge University Press, Cambridge, 2001, p 564-65

32 Australian Kfarsghab Association, 29 January 2008, 'Historic Events', no 23, http://www.kfarsghab.com.au/HistoricalEvents.htm

33 Petronella Fakhry, 'Becharrie Pioneers to Australia', Becharrie News, vol 36, July, 2001, pp 6-7

34 Peter McDonald, Community Profiles: Lebanon Born, Department Immigration, Multicultural and Ethnic Affairs, Canberra, 2000

35 Anne Monsour, and Paul Convy, 'A Thematic History of the Lebanese in New South Wales' unpublished manuscript, due for publication by the Heritage Office of NSW in May 2008, and available on their website

36 Hall Greenland, 'Brothers in Arms’, Bulletin, 8 August 2006, pp 20-21

37 Anne Monsour, ‘What Jiddi Didn’t Tell Us: Using Documentary Evidence to Understand the Settlement of Syrian/Lebanese Immigrants in Queensland, Australia from the 1880s to 1947, in Paul Tabar (ed), Lebanese Diaspora: History, Racism and Belonging, Lebanese American University, Beirut, 2005, pp 57-81;

38 Anne Monsour, 'Whitewashed: the Lebanese in Queensland, 1880-1947', in Ghassan Hage, (ed), ArabAustralians Today: Citizenship and Belonging, Melbourne University Press, Melbourne, 2002, p 17 


\section{Endnotes}

39 Anne Monsour, 'Becoming White: How Early Syrian/Lebanese in Australia Recognised the Value of Whiteness' in Leigh Boucher, Jane Carey and Katherine Ellinghaus (eds), Historicising Whiteness: Transnational Perspectives on the Construction of an Identity, RMIT Publishing in association with the School of Historical Studies, University of Melbourne, Melbourne, 2007, pp 124-32

40 Alexander T Yarwood, Asian Migration to Australia: The Background to Exclusion 1896-1923, Melbourne University Press, Melbourne, 1967, pp 141-50

41 Anne Monsour, 'Becoming White: How Early Syrian/Lebanese in Australia Recognised the Value of Whiteness' in Leigh Boucher, Jane Carey and Katherine Ellinghaus (eds), Historicising Whiteness: Transnational Perspectives on the Construction of an Identity, RMIT Publishing in association with the School of Historical Studies, University of Melbourne, Melbourne, 2007, pp 124-32

42 See for instance: Jock Collins, et al, Kebabs, Kids, Cops \& Crime:Youth, Ethnicity and Crime, Pluto Press, Sydney, 2000; Scott Poynting, et al, Bin Laden in the Suburbs: Criminalising the Arab Other Sydney Institute of Criminology, Sydney, 2004 